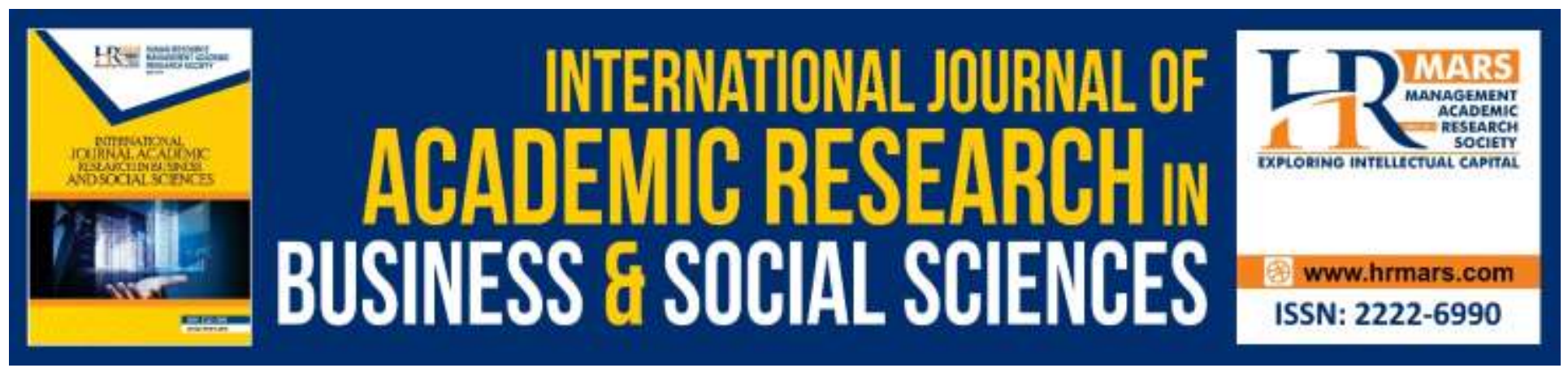

\title{
Does Sustainability Respond to Sensitivity to Risk? The Case of Insurance Companies in Kenya
}

Johannes Mwangangi Kitaka, David Kiragu, Simmy M. Marwa

To Link this Article: http://dx.doi.org/10.6007/IJARBSS/v10-i5/7243

DOI:10.6007/IJARBSS/v10-i5/7243

Received: 02 March 2020, Revised: 12 April 2020, Accepted: 29 April 2020

Published Online: 27 May 2020

In-Text Citation: (Kitaka et al., 2020)

To Cite this Article: Kitaka, J. M., Kiragu, D., \& Marwa, S. M. (2020). Does Sustainability Respond to Sensitivity to Risk? The Case of Insurance Companies in Kenya. Internatinal Journal of Acdemic Research in Business and Social Sciences, 10(5), 714-729.

\section{Copyright: (c) 2020 The Author(s)}

Published by Human Resource Management Academic Research Society (www.hrmars.com)

This article is published under the Creative Commons Attribution (CC BY 4.0) license. Anyone may reproduce, distribute, translate and create derivative works of this article (for both commercial and non-commercial purposes), subject to full attribution to the original publication and authors. The full terms of this license may be seen

at: http://creativecommons.org/licences/by/4.0/legalcode

Vol. 10, No. 5, 2020, Pg. 714 - 729

http://hrmars.com/index.php/pages/detail/IJARBSS

JOURNAL HOMEPAGE

Full Terms \& Conditions of access and use can be found at http://hrmars.com/index.php/pages/detail/publication-ethics 


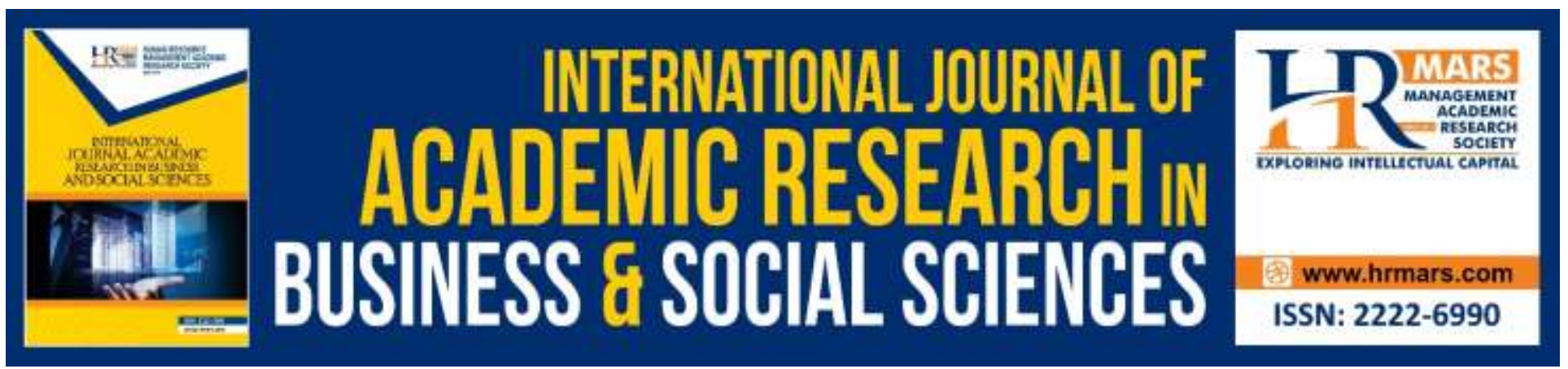

\title{
Does Sustainability Respond to Sensitivity to Risk? The Case of Insurance Companies in Kenya
}

\author{
Dr. Johannes Mwangangi Kitaka(PhD), Prof. David Kiragu (PhD), \\ Prof. Simmy M. Marwa (PhD)
}

Department/School: School of Business Management \& Economics, Dedan Kimathi University of

Technology, Nairobi, Kenya.

Email.joekyutu67@gmail.com,drkiragu@gmail.com / dkiragu@dkut.ac.ke, mwitamarwa@yahoo.com / simmy.marwa@dkut.ac.ke

\begin{abstract}
Purpose: To determine how Sensitivity to Risk influence Sustainability of Insurance Companies in Kenya.
\end{abstract}

Methodology: The study adopted the positivist research philosophy and employed a descriptive research design. The target population was the 51 insurance companies as registered by the Insurance Regulatory Authority of Kenya (IRA) as at $31^{\text {st }}$ December 2016. The study took a proportionate sample of 30 companies composed of 10 life, 15 general and 5 composite insurance companies respectively. The data analysis was by multiple regression analysis, performed to determine the relationship of the independent variable of Sensitivity to Risk and the dependent variable of Sustainability. The study used descriptive statistics such as the mean, standard deviation and frequencies to analyze the data. Further, the study applied inferential statistics such as the ANOVA and the T-test for further analysis.

Study Findings: The results of the study were that Sensitivity to Risk has a positive and significant effect on sustainability of insurance companies in Kenya. The study results further concluded that the operations of the board risk committees in an insurance firm, in addition to appointment of risk champions to identify and track risks enhanced the insurance company's sustainability.

Unique Contribution: The risk based supervision regime (RBC) which came into operation in the country in 2015 is a key change in the industry, which will affect the industry players in a large way. However, the level of compliance has been quite low, as the minimum required solvency level has been set at $100 \%$ with the dates of full compliance being pushed to 2020 from the original date of December 2018. The extension of compliance date imply that most insurance companies would largely remain non-compliant during this period. The risk-based supervision, though being a step in the right direction, the model does not capture factors that enhance an insurance company's sustainability. There are other various factors relating to agility like technological adoption and advancement in service and product innovation, which have not been included though key to a company sustainability. Further, there are a few measures adopted by companies to combat climate 
change but measurement and reporting of the same has not been taken care of in the current RBC framework. The IRA monitors and approves the insurance company's staff in senior management level and directors through the 'fit and proper' process. In the Fit and Proper' process of monitoring and approval, little is captured in the annual reporting or review through either a sustainability or agility index or even bringing in a management capability index. Therefore, it would be of great interest for IRA to open up the RBC model to bring in agility, sustainability and management indices. Keywords: Sensitivity to Risk, Sustainability, Insurance Companies, Agility Index, Management Capability Index, Sustainability Index.

\section{Introduction}

The collapse of an insurance company exposes policyholders to losses in terms of likely inability of the insurance company to settle the policyholder's claims in a timely manner when they fall due. In case of catastrophe occurring and affecting their businesses or lives, the policyholders would lose the premiums which they will have paid at the time of the insurance company's collapse and thus suffer loss of savings and assets and likelihood of litigations from affected third parties. The policyholder would face reduced benefits while the industry and company would suffer from negative perception of their role in the market and policyholders lives. Further, the acceptability of insurance services will diminish after an insurance company's failure. As an example, the insurance industry in German has faced few insolvency incidences over time. The limited insolvencies were due to a regulatory regime that encourages companies to record assets at market values, as they have to disclose the market values of the assets and therefore little financial statements understatements. There is limited competition, which could reduce the premium rate charges. The existence of low premium charges can lead to poor pricing and unhealthy underwriting margins as the insurance companies can set their rates across borders and a tax law that encourages prudent reserving, as it does not penalize over reserving and development of products that have exposure limits (AMBest, 2009).

Many businesses across the world continue to measure sustainability in terms of environmental and social performance (Debra et al., 2015). These measurements use people and planet as the only measure of sustainability, leaving out the profit part (PwC, 2013). Jones (2011) notes that the US insurance industry continue to make huge claims payments due to the effects of climate change. Out of 426 US Insurance companies that collapsed (AM Best, 2009), 43\% of the collapsed companies was due to management failures, $31 \%$ due to insensitivity to risk, $20 \%$ due to capital inadequacy and $6 \%$ due to inappropriate investment policies and instruments. These performance issues raise the question of insurance industry sustainability and agility. The world over, countries continue to face sustainability challenges in terms of climate change and its effects on businesses, societies and overall stability of the affected countries (UNEP). The effects of climate change affect the poor and other vulnerable groups in society and therefore the concern for sustainable insurance industry to foster stability and increase capacity for savings mobilization.

\section{Problem Statement}

The performance of the insurance industry in Kenya has dropped drastically from a profit of Kes 0.2 million in 2001, to a loss of Kes 0.2 billion in 2015(IRA, 2015). This poor performance trend continued in 2016 when the industry losses further deteriorated to Kes 2.3 billion (IRA, 2016). The dismal performance, with largely no growth at the underwriting level was occasioned by the industry's inability to contain claims costs, high management expenses and acquisition costs. The dismal 
performance, therefore may render the industry to be unprofitable and unsustainable. The insurance penetration in Kenya, which stood at a low of $2.75 \%$ compared to the global rateof $6 \%$ by 2016 , shows a dismal performance trend. The low level of insurance penetration is however largely above other regional countries though poor and unsustainable. Low insurance penetration may on the other hand reflect an industry where there is room for growth if service and product innovation are pursued (TIRA, 2013).

Many insurance companies have faced persistently poor investment practices and non-compliance to cash and carry law, leading to poor collection of premiums (Jones, 2011). The slow innovation and adoption to new technology; significant shortage of skilled staff, capital inadequacy, mis-selling by insurance intermediaries and severe price undercutting among the many competitors has led to the collapse of 7 companies, representing $16 \%$ of the companies in operation. The collapse of the insurance companies resulted into loss of employment, reduction in taxes paid to the government and loss of shareholder capital. The collapse of the insurance companies meant inability to pay claims in full and at times resulting to ultimate collapse of social and economic pillars of a country. The collapse of insurance companies coupled with asset and liability mismatch, rampant fraud and mismanagement necessitated the determination into how sensitivity to risk influenced the sustainability of insurance companies in Kenya. It can therefore be concluded that many insurance companies have not adequately responded to sensitivities in liquidity risk, reinsurance risk, capital management risk, fraud risk, money laundering risk, reputational risks, counterparty risk, regulatory risk and people risk (Bhoola \& Madzhadzhi, 2014; Narayan, Strydom \& Heerden, 2014).

\section{Literature Review}

\section{Theoretical Literature Review}

The financial distress theory asserts that financial distress occurs in four stages. The four stages of financial distress theory include company performance deterioration, company failure, company insolvency and the company going through various default intervals. Whereas deterioration of performance and company failure affect the company's profitability, the company's insolvency and frequent occurrence of default are caused by its level of liquidity. Theoretically, the outcome of each financial distress stage can be positive, implying that the company breaks the downward trend, or negative trend. These company breaks indicate the continuing deterioration of the company value and a downwards movement from one stage of the spiral to another. In many real cases, when entering financial distress, the company moves through all the phases of decline (Mueller, 1986). In addition, financial distress, as characterized by a sharp decline in the company's financial performance and value (Opler \& Titman, 1994), is part of the overall process, which has two important characteristics; moving down the spiral from one stage to another. The sharp decline accelerates, whereas the length of each stage becomes shorter and shorter. The financial performance deterioration can continue longer than the economic failure of the company. The length of insolvency depends on the maturity structure of the firm's debt, whereas default is dependent on the date of maturity, followed by renegotiation and turnaround or liquidation and is, therefore, the shortest stage of financial distress. The challenge to financial distress is the early recognition of adverse processes in order to gain more time to prepare for response. The delay in anticipating occurrence of financial distress brings in more time pressure and makes the success of counter measures questionable (Opler \& Titman, 1994). The financial distress theory is therefore relevant to 
INTERNATIONAL JOURNAL OF ACADEMIC RESEARCH IN BUSINESS AND SOCIAL SCIENCES

Vol. 10, No. 5, May, 2020, E-ISSN: 2222-6990 @ 2020 HRMARS

the study as it informs the dependent variable, which is sustainability, in addition to explaining the causes of the challenges facing the insurance companies.

\section{Empirical Literature Review}

According to Abideen and Saleem (2011) sensitivity covers how response to particular risk exposures can affect the performance of an institution. They report that risk management as the identification, the assessment, the monitoring and controlling of the identified risks. An efficient process of risk management leads to a better decision making process for the growth and better management of the company. The study concluded that organizations that apply risk management practices have a high financial performance leading to a higher competitive hedge in the market. The financial risk has not been adequately responded to in the local market as many insurance companies have been underperforming and making losses. Sean (2015) while investigating the influence of government regulation on the insurance sector states that risk sensitivity covers how specific hazard exposures can influence establishments. Credit supervisors evaluate an establishment's affectability to market risk by checking the administration of credit process. The supervisors can monitor how loan advancement to particular businesses influence an organizations performance. The regulatory risk is key in Kenya. There are many laws coming into place that may affect the way companies conduct the business of insurance. A case in point in the new capital and risk based capital requirements.

While reviewing risk management and its influence on the performance insurance companies in Kenya, focused particularly on AIG Insurance Company where most of the respondents worked, Wanjohi and Ombui (2013) selected respondents for the study, by randomly sampling 51 companies and data obtained through a questionnaires. The data analyzed and its findings were presented using descriptive statistics of frequency distribution tables, pie charts and bar graphs. The findings of the study revealed that the underlying causes of operational risk losses are not always initially observable. They concluded that it was hard to identify the sequence of event occurrences that that prompt the misfortune. On governance risk, management through trainings and related exercises focused on building familiarity with the significance of Enterprise Risk Management (ERM), parts and obligations and benefits obtained from ERM. These outcomes point to proper concentration on risk administration since significant, on time data hazard and duties. Diminished undertaking IT support, spending plans and expanded simplicity of innovation arrangements has prompted numerous shadow IT organizations in the ventures. On key risk administration, sheets are seeing quick increments both in the speed with which chance occasions happen and the infection with which they spread crosswise over various classes of risk. They are particularly worried about the heightening effect of calamitous dangers, which can debilitate an association's exceptionally presence and even undermine whole businesses. Companies that do not respond to technology may end up not being competitive. With constant technologies changes, companies need to set aside funds for to invest in the same. Cyber security is becoming a constant theme across the globe. Therefore, insurance companies need to respond with an appropriate product to address customer needs for cyber security.

Omasete (2014) conducted an exploratory study targeting the 49 registered insurance companies in Kenya, using both primary and secondary data. In this study, the focus was on risk management framework of insurance companies. He investigated risk management practices and their effects on the Kenyan insurance companies' financial performance. The study found out that a dominant part 
INTERNATIONAL JOURNAL OF ACADEMIC RESEARCH IN BUSINESS AND SOCIAL SCIENCES Vol. 10, No. 5, May, 2020, E-ISSN: 2222-6990 @ 2020 HRMARS

of insurance agencies in Kenya had received risk management training in their operations which strongly affected their financial strategy execution. He observed risk identification significantly affected financial strategy execution, followed by risk mitigation, risk management program implementation and monitoring and risk assessment \& measurement respectively. The investigation infers that there is a positive relationship between the application of hazard management practices and the financial performance of insurance companies in Kenya.

Mwangi (2014) examined risk management and its effect on financial performance of commercial of banks in Kenya. Using descriptive research design as a part of the investigation, the researcher gathered secondary data from Central Bank and the banks financial. The data was analyzed using multiple regression. The study found a strong and positive relationship between risk management and financial performance of commercial banks in Kenya. The study found negative relationship between credit risk, insolvency risk, interest rate risk and financial performance of commercial banks in the country. Amaya and Memba (2015) investigated risk management practices and its influence on financial performance of life assurance companies in Kenya. During this study, they covered insurance companies operating in Kisii County. The target population was 118 respondents who were used to collect data through a census method, using questionnaires and analyzed it using descriptive statistics of percentages, frequency tables and regression equations. The researchers concluded that claims and benefits paid to policyholders of insurance companies' increases the investment value of their investment. The study gives the reason for claims adjusters to get the best estimate of acceptable costs for every policy holder. The overall claims costs is determined by observed costs based on various risk factors.

Osiemo (2016) examined risk management practices and their effects on financial performance of non-life insurance companies in Kenya. He focused his study on the companies operating in Kisii County. The researcher, collected data using descriptive survey research design, targeting a population of 237 respondents comprising of 116 directors and 121 senior managers involved in risk management of ten selected insurance companies. Sample size was forty-eight respondents, which represent $20 \%$ of target population collected through stratified random sampling method using a structured questionnaire. Further, they collected secondary data from published reports and financial statements presented to IRA for the five years period between 2010 and 2014 then analyzed using descriptive and inferential statistics. The study findings indicated that risk identification, risk mitigation, risk monitoring and risk management practices had a significant and positive effect on financial performance of non-life insurance companies. Nyagah (2014) did a study to determine the level of implementation of enterprise risk management systems by pension fund management companies in Kenya. He further assessed the effect of enterprise risk management systems on their financial performance. The coefficient results showed that risk event identification, risk assessment, risk departments objective setting, and eventual information communication had negative effects on the financial performance of fund management companies. At the same time, the response to risk events, the internal environment under which an organization operates in and control activities exercised by the company had positive effects on the financial performance. However, the effects of event identification and risk response on company's financial performance were insignificant at 5\% level. Thus, the study concluded that enterprise risk management practices largely influences the financial performance. 
INTERNATIONAL JOURNAL OF ACADEMIC RESEARCH IN BUSINESS AND SOCIAL SCIENCES Vol. 10, No. 5, May, 2020, E-ISSN: 2222-6990 @ 2020 HRMARS

Waweru and Ngugi (2014) explored the impact of financial management practices on the performance of Micro and Small Enterprises in Kenya. The research variables were financial innovations, investing activities, risk management practices and working capital management. The study results indicated that financial innovations largely influenced the performance of Micro and Small Enterprises in Kenya. The study further concluded that risk has become part of strategic components of the modern organization's survival and success. Finally, the study concluded that a statistical significant relationship existed between working capital and company performance. Financial innovation influences performance, risk management has become part of strategic management and there is a significant statistical relationship between working capital and a company's performance (Waweru \& Ngugi, 2014). Nyagah (2014) found evidence of risk identification, risk assessment, objective setting and information communication as having negative influence on fund management performance. Osiemo (2016) on the other hand records that risk identification, risk mitigation, risk monitoring and management as having significant and positive influence of financial performance of life insurance companies. These divergent results from prior studies support the formulation of the third hypothesis $\mathrm{H}_{0} 3$ that Sensitivity to Risk does not influence the sustainability of insurance companies in Kenya.

\section{Conceptual Framework}

The role of conceptual framework is to depict the relationship between Sensitivity to Risk, which is the independent variable, and Sustainability, which is the dependent variable (Dodge, 2009). Sustainability of insurance companies responds to the changes of sensitivity to risk parameters (Everitt, 2009).

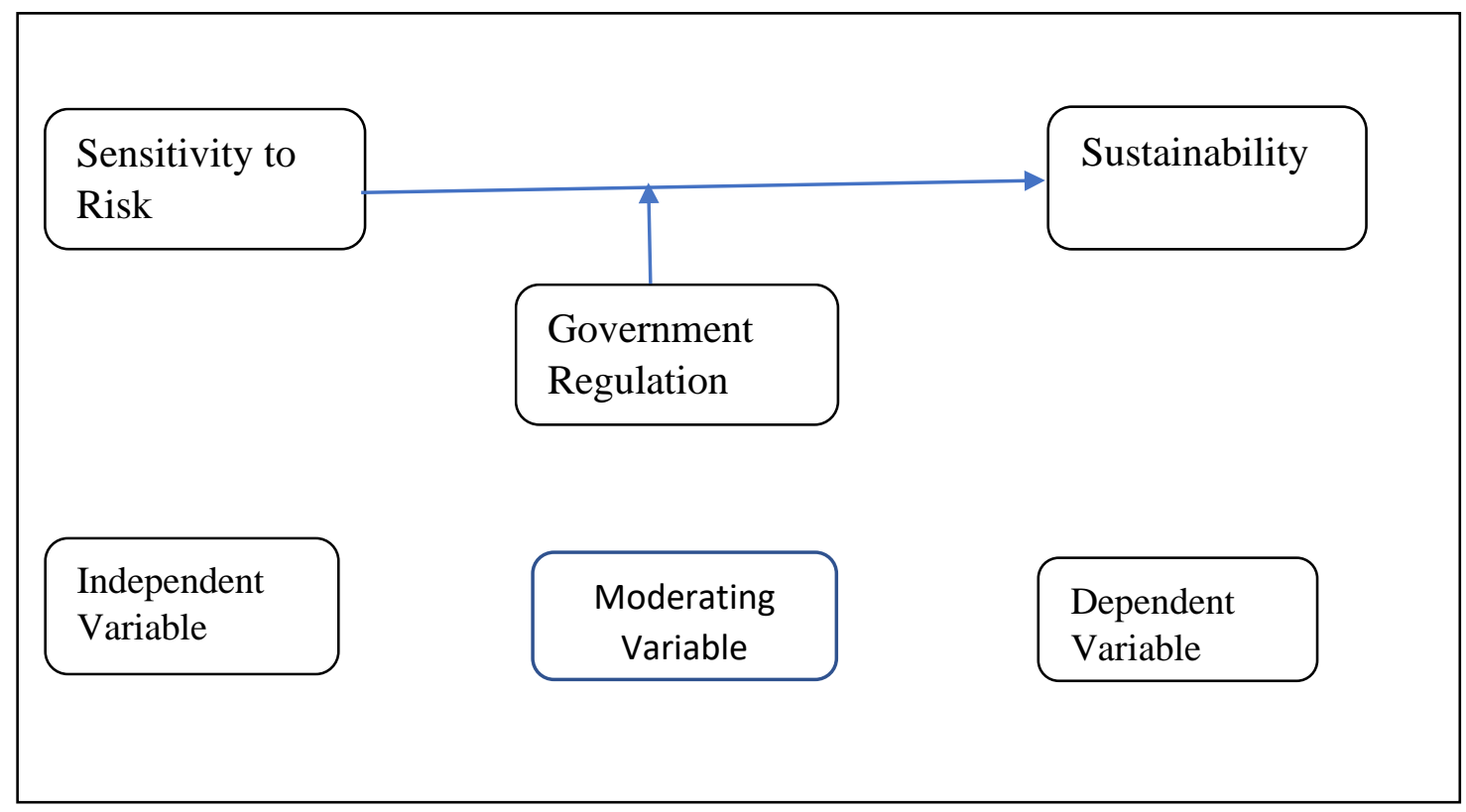

Figure 1. Conceptual Framework for Drivers of 
INTERNATIONAL JOURNAL OF ACADEMIC RESEARCH IN BUSINESS AND SOCIAL SCIENCES

Vol. 10, No. 5, May, 2020, E-ISSN: 2222-6990 @ 2020 HRMARS

\section{Sustainability \\ Research Methodology}

The study adopted the positivist research philosophy and employed a descriptive research design during the research process. The target population was the 51 insurance companies as registered by the Insurance Regulatory Authority of Kenya as at $31^{\text {st }}$ December 2016, of which the researcher proportionately chose 30 companies, being 10 from life, 15 from general and 5 from composite insurance companies respectively. Using probabilistic procedures for data collection and employing stratified random sampling method, the researcher collected the required data. Primary data collection was through a questionnaire with closed questions. A pilot study before questionnaire distribution ensured their validity and reliability, before distribution by email, followed by a telephone call to the respondents and a research assistant visiting the respondents to collect them. The period of the study was 2001-2015, a period during which the industry faced turbulence, increased regulation and collapse of several insurance companies. The researcher collected data by sampling 357 staff from senior, middle and junior cadres of the 30 insurance companies. The raw data was cleaned, edited, coded and analyzed using SPSS tool to generate descriptive and inferential statistics while secondary data was collected using data collection sheets. Data analysis using multiple regression analysis was performed to determine the relationship of each of the independent variables to the dependent variable. The researcher used descriptive statistics such as the mean, standard deviation and frequencies to analyze the data. Further, the study applied inferential statistics such as the ANOVA and the T-test for further analysis

\section{Results}

\section{Descriptive Results}

The study sought to explore how sensitivity to risk influence sustainability of insurance companies in Kenya. Data was collected from the respondents who indicated their levels of agreement using a five point Likert scale where 1 = strongly disagree, 2 = Disagree $3=$ Neutral, $4=$ Agree, $5=$ strongly agree. For the purposes of interpretation, the data was further, with $4 \& 5$ (agree and strongly agree) being grouped together as agree, $1 \& 2$ (strongly disagree and disagree) were grouped as disagree while 3 was neutral. The descriptive on sensitivity to risk and sustainability of insurance companies in Kenya, which suggest that $81.6 \%$ of the respondents agreed that the operations of the board risk committee, enhances the sustainability of the insurance companies where they were employed. These findings are in line with those of Osiemo (2016) who suggested that risk committee helped to improve the sustainability of the insurance companies. In addition, $79.0 \%$ of the respondents agreed that the appointment of risk champions who aid in the identification and tracking of various company risks enhanced the company's sustainability, with $85.5 \%$ of them agreeing that the performance of risk surveys for all insurance risks before going on cover enhanced company sustainability. These findings agreed with those of Mushtaq Ismail and Hanif (2015) that the work of risk champions boosts sustainability. From the study results, $69.6 \%$ of the respondents agreed that the company's reinsurance program ensured continued insurance company sustainability, which is in line with that of Wanjohi and Ombui (2013) that companies with reinsurance programs are sustainable.

On a five point scale, the average mean of the responses was 3.95, which means that majority of the respondents agreed with the statements; however the answers were varied as shown by a standard deviation of 1.19. The commonality of the structure, company size and culture in the insurance sector showed a sector that is highly regulated and the high level of competition with severe price 
undercutting has not helped in moving some of the companies to a dominant position and therefore becoming centres of excellence in terms of risk management practices.

The IRA variously reports of the lack of compliance to risk rating guidelines, the level of uncollected premiums, and the reported underwriting losses among other factors are reflection of companies and an industry, which is yet to adopt the best standards of risk management. In fact, the IRA reports enumerate the many ills facing the industry, raising the question of inadequate and unintegrated risk management practices to mitigate against the risk exposures facing the industry.

\section{Factorability Test for Sensitivity to Risk}

\section{Sampling Adequacy for Sensitivity to Risk}

To ascertain the various significant measures of sensitivity to risk for further analysis through regression and ensure the insignificant ones are dropped, the various sensitivity to risk measures were analysed using Cronbach Alpha Test of reliability. The factors that scored less than 0.5 were dropped during the regression analysis. The purpose of factor analysis for sensitivity to risk is to enable the study to pick the significant measures for regression analysis while the insignificant ones are dropped from any further consideration.

\section{Measure of Sampling Adequacy for Sensitivity to Risk}

To examine whether the data collected was adequate and appropriate for inferential statistical tests such as the factor analysis, multiple linear regression analysis and other statistical tests, two main tests were performed namely; Kaiser-Meyer-Olkin (KMO) Measure of Sampling Adequacy and Barlett's Test of Sphericity. For a data set to be regarded as adequate and appropriate for statistical analysis, the value of KMO should be greater than 0.5 (Field, 2000). The study findings showed that the KMO statistic at 0.751 was significantly high; that is greater than the critical level of significance of the test, which was set at 0.5 .

Table 1: Results of Factorability Test for Sensitivity to Risk

\begin{tabular}{llc} 
Kaiser-Meyer-Olkin Measure of Sampling Adequacy & $\mathbf{0 . 7 5 1}$ \\
\hline Bartlett's Test of Sphericity & Approx. Chi-Square & 235.366 \\
& Df & 21 \\
& Sig. & 0.000 \\
\hline
\end{tabular}

In addition to the KMO test, the Bartlett's Test of Sphericity was also highly significant (Chi-Square = 235.366 with 21 degree of freedom, at $p<0.05$ ). These results provide an excellent justification for further statistical analysis to be conducted.

\section{Communalities for Sensitivity to risk}

For Sensitivity to Risk, to determine the extent of how each of the variables of Sensitivity to Risk measures accounted for the Sensitivity to Risk factor taken together, a communality analysis was performed. According to Kothari and Garg (2014) communalities should be 0.5 or greater for better measurement of factor analysis and therefore a high value of communality means that not much of the variable is left over after whatever factors represented taken into consideration. 
INTERNATIONAL JOURNAL OF ACADEMIC RESEARCH IN BUSINESS AND SOCIAL SCIENCES

Vol. 10, No. 5, May, 2020, E-ISSN: 2222-6990 @ 2020 HRMARS

Table 2: Results of Communalities for Sensitivity to risk

\begin{tabular}{llcc}
\hline Variable & Statement & Initial & Extraction \\
\hline SR 1 & $\begin{array}{l}\text { The operations of the board risk committee enhances its } \\
\text { sustainability }\end{array}$ & 1 & 0.601 \\
SR 5 & $\begin{array}{l}\text { The disaster recovery and business continuity plan of the } \\
\text { company enhances its sustainability }\end{array}$ & 1 & 0.565 \\
SR 2 & $\begin{array}{l}\text { The appointment of risk champions to identify and track risks } \\
\text { enhances the company's sustainability }\end{array}$ & 1 & 0.510 \\
SR 4 & $\begin{array}{l}\text { The company's reinsurance program ensures continued } \\
\text { sustainability of the company } \\
\text { The risk based premium rating of the company ensures for } \\
\text { Sustainable business }\end{array}$ & 1 & $\mathbf{0 . 4 9 2}$ \\
SR 6 & $\begin{array}{l}\text { The performance of risk surveys for all insurance risks before } \\
\text { going on cover enhances the company's sustainability }\end{array}$ & 1 & $\mathbf{0 . 3 0 7}$ \\
\hline
\end{tabular}

According to Kaiser (1974), factor-loading values that are greater than 0.4 should be accepted and values below 0.5 should lead to collection of more data to help researcher to determine the values to include. Values between 0.5 and 0.7 are mediocre, values between 0.7 and 0.8 are good, values between 0.8 and 0.9 are great, and values above 0.9 are superb. Factor analysis was conducted on statements regarding sensitivity to risk and three statements had a coefficient of less than 0.5 and hence were dropped for descriptive analysis.

\section{Total Variance Explained for Sensitivity to Risk}

The study extracted eigenvalue of each of the extracted factors of sustainability to risk and arranged by value from the highest to the lowest. The total explained variance results shows all the factors extractable from the analysis along with their eigenvalues, whose sum should be equal to number of items, which are further subjected to factor analysis. The aim of the Eigenvalue analysis is to drop the factors that are less than 0.850

Table 3 Results Total Variance for Sensitivity to Risk

\begin{tabular}{lrrrrrc}
\hline Component & \multicolumn{2}{c}{ Initial Eigenvalues } & \multicolumn{3}{c}{ Extraction Sums of Squared Loadings } \\
& Total & \% of Variance & Cumulative \% & Total & \% of Variance & Cumulative \% \\
\hline SR 1 & 2.286 & 38.103 & 38.103 & 2.286 & 38.103 & 38.103 \\
SR 5 & 0.931 & 15.519 & 53.622 & 0.931 & 15.519 & 53.622 \\
SR 2 & 0.847 & 14.124 & 67.747 & 0.847 & 14.124 & 67.746 \\
SR 4 & 0.763 & 12.723 & 80.470 & & & \\
SR 6 & 0.647 & 10.785 & 91.255 & & & \\
SR 3 & 0.525 & 8.745 & 100.000 & & & \\
\hline
\end{tabular}

The Varimax rotation tries to maximize the variance of each of the capital adequacy factors. The study results therefore mean that the three factors that were retained out of the six components explained $67.75 \%$ of the total variations. 
INTERNATIONAL JOURNAL OF ACADEMIC RESEARCH IN BUSINESS AND SOCIAL SCIENCES Vol. 10, No. 5, May, 2020, E-ISSN: 2222-6990 ㄷ 2020 HRMARS

\section{Scree Plot for Sensitivity to Risk}

The study plotted the latent roots, eigenvalue, against the factors in order of extraction the into scree graph to aid in deciding which of the factors was to be dropped from any further consideration. From the third factor on, the line is almost flat, meaning the each successive factor is accounting for smaller and smaller amounts of the total variance.

\section{Rotated Component Matrix for Sensitivity to Risk}

The sensitivity to risk measures factors were rotated so as to reduce the number of factors on which variables under investigations have high loadings. The aim of rotation is mainly for making interpretation easier as several factors were loaded around a certain factor component where they have a similarity. The results imply that the sensitivity to risk measures are combined into one factor with various scores.

\section{Table 4: Results of Rotated Component Matrix for Sensitivity to Risk}

\begin{tabular}{|c|c|c|}
\hline Parameter & Statement & 1 \\
\hline SR 5 & $\begin{array}{l}\text { The company's reinsurance program ensures continued sustainability of the } \\
\text { company }\end{array}$ & 0.697 \\
\hline SR 1 & The operations of the board risk committee enhances its sustainability & 0.695 \\
\hline SR 2 & $\begin{array}{l}\text { The appointment of risk champions to identify and track risks enhances the } \\
\text { company's sustainability }\end{array}$ & 0.618 \\
\hline SR 6 & $\begin{array}{l}\text { The disaster recovery and business continuity plan of the company enhances its } \\
\text { sustainability }\end{array}$ & 0.688 \\
\hline SR 7 & The risk based premium rating of the company ensures for sustainable business & 0.510 \\
\hline SR 4 & $\begin{array}{l}\text { The performance of risk surveys for all insurance risks before going on cover } \\
\text { enhances the company's sustainability }\end{array}$ & 0.384 \\
\hline
\end{tabular}

The study results imply that five (5) statements (SR1,SR2,SR4,SR5,SR6 and SR7), can be combined into one factor while 1 statement (SR 3) cannot be combined with another factor and therefore the appointment of risk champions to identify and track risks may not significantly enhance the insurance company's sustainability. Therefore, statement SR4 was dropped from any further analysis. Therefore, the final analysis for sensitivity to risk consisted of only one factor. The variables, which were considered in the final analysis for sensitivity to risk, are reinsurance programs, functioning board risk committees, disaster recovery and business continuity plans, risk champions and risk based premium rating.

\section{Correlation Test}

As regards the correlation between sensitivity to risk and sustainability of insurance companies, the results of operations of board risk committee and sustainability of insurance companies have a positive and significant relationship $(r=0.366, p=0.000)$ as supported by Osiemo (2016) who found that risk committees helps to improve the sustainability of the insurance companies. Further, the appointment of risk champions to identify and track risks as supported by Mushtaq Ismail and Hanif (2015) have a positive and significant relationship $(r=0.539, p=0.000)$. 
INTERNATIONAL JOURNAL OF ACADEMIC RESEARCH IN BUSINESS AND SOCIAL SCIENCES

Vol. 10, No. 5, May, 2020, E-ISSN: 2222-6990 @ 2020 HRMARS

In addition, reinsurance programs have a positive and significant relationship $(r=0.390, p=0.000)$ as supported by Wanjohi and Ombui (2013) who argued that companies with reinsurance programs are sustainable. Finally, the existence of a disaster recovery and business continuity plan have a positive and significant relationship $(r=0.419, p=0.000)$ which was evidenced by Baxter (2007) who concluded that business continuity plans of the company enhances its sustainability.

\section{Regression Analysis}

The objective of the study $\mathrm{H}_{0}$ was to examine how sensitivity to risk influenced sustainability of insurance companies in Kenya. Regression analysis was used to examine whether sensitivity to risk can be used to explain sustainability of the insurance companies in Kenya. The regression results present the fitness of model used for the regression analysis in explaining the study phenomena.

Table 5: Model Fitness Results for Sensitivity to Risk

\begin{tabular}{lr}
\hline Variables & Coefficients \\
\hline$R$ & 0.610 \\
$R^{2}$ & 0.373 \\
Adjusted $R^{2}$ & 0.363 \\
Std. Error of the Estimate & 0.475 \\
\hline
\end{tabular}

Sensitivity to Risk was found to be satisfactory in explaining sustainability of insurance companies which is supported by coefficient of determination also known as the $R^{2}$ of $37.3 \%$ (Table 5 ) suggesting the model fitness found out that Sensitivity to Risk explain $37.3 \%$ of the variations in the dependent variable which is sustainability of the insurance companies. The analysis of the variance (ANOVA) results (Table 6) indicated that the model was statistically significant implying that the Sensitivity to Risk is a good predictor of sustainability of insurance companies. The findings are supported by an Fstatistic of 40.23 and the reported $p$-value (0.000) which was less than the conventional probability of 0.05 significance level.

Table 6: ANOVA Results for Sensitivity to Risk

\begin{tabular}{lccccc}
\hline Measure & Sum of Squares & Df & Mean Square & F & Sig. \\
\hline Regression & 36.319 & 4 & 9.08 & 40.23 & $\mathbf{0 . 0 0 0}$ \\
Residual & 61.163 & 271 & 0.226 & & \\
Total & $\mathbf{9 7 . 4 8 1}$ & $\mathbf{2 7 5}$ & & & \\
\hline
\end{tabular}

The study tested the null hypothesis that Sensitivity to Risk did not affect the Sustainability of Insurance Companies in Kenya using multiple linear regression. The reject or fail to accept criteria was that, if the $p$ value is greater than 0.05 , the $H_{o}$ is not rejected but if it's less than 0.05 , the $H_{o}$ fails to be accepted. The null hypothesis was that there was no significant relationship between sensitivity to risk and sustainability of insurance companies in Kenya. The regression results (Table 7) show that the $p$-value was $0.000<0.05$, leading to rejection of the null hypothesis indicating there was a significant relationship between sensitivity to risk and sustainability of insurance companies in Kenya. 
INTERNATIONAL JOURNAL OF ACADEMIC RESEARCH IN BUSINESS AND SOCIAL SCIENCES Vol. 10, No. 5, May, 2020, E-ISSN: 2222-6990 @ 2020 HRMARS

Table 7: Regression Coefficients for Sensitivity to Risk

\begin{tabular}{lcccc}
\hline Variable & B & Std. Error & t & Sig. \\
\hline (Constant) & 2.195 & 0.139 & 15.841 & 0.000 \\
Operations of the Board Risk Committee & 0.078 & 0.028 & 2.767 & 0.006 \\
Appointment of Risk Champions & 0.235 & 0.03 & 7.933 & 0.000 \\
Company's Reinsurance Program & 0.086 & 0.025 & 3.383 & 0.001 \\
Disaster Recovery and Business Continuity Plan & 0.031 & 0.026 & 1.167 & $\mathbf{0 . 2 4 4}$ \\
\hline
\end{tabular}

The relationship between operations of board risk committee and sustainability of insurance companies have a positive and significant relationship $(r=0.078, p=0.006)$ which is supported by Osiemo (2016) that risk committees help to improve the sustainability of the insurance companies. In addition the results of appointment of risk champions to identify and track risks have a positive and significant relationship ( $r=0.235, p=0.000$ ) that of Mushtaq Ismail and Hanif $(2015)$ that risk champions boosts insurance companies sustainability. Further the reinsurance programs have a positive and significant relationship $(r=0.086, p=0.001)$ as postulated by Wanjohi and Ombui (2013) that companies with reinsurance programs are sustainable. Finally, the results of disaster recovery and business continuity plans have a positive and insignificant relationship $(r=0.031, p=0.244)$ as supported by Baxter (2007) that business continuity plan of the company enhances its sustainability. Therefore, disaster recovery was dropped in the final regression model for sensitivity to risk variable.

\section{Regression model}

$Y_{3}=2.195+0.078 B_{r}+0.235 R_{c}+0.086 R_{e}+\varepsilon$ where $Y_{3}=$ Sustainability, $B_{r}$ - Operations of The Board Risk Committee, $R_{c}$ - Appointment of Risk Champions, Re - Company's Reinsurance Program and $\varepsilon$ - Error term

\section{Conclusions and Recommendations Conclusions}

The objective of the study was to examine how sensitivity to risk influenced the sustainability of insurance companies in Kenya. The operations of the board risk committees in an insurance company enhanced its sustainability which is in line with Saleem and Abideen (2011). Most of the insurance companies had appointed risk champions to identify and track risks so as to minimize exposures to severe claim occurrences, in addition to having reinsurance programs; disaster recovery and business continuity plans that ensured risk mitigation of the various risks that the insurance companies face in their conduct of insurance business. These findings are in line with those of Wanjohi and Ombui (2013).

Insurance companies should move towards a process of risk management that encompasses risk surveys and valuations before risk on - boarding, management of accidents and post - accident reviews and confirmation of the insurance risks before they are brought to book and insurance cover issuance as per Amaya and Memba (2015). The process of risk management cannot be an individual company affair, but the whole industry should take a collaborative approach towards risk management.

The collaborative risk management approach will ensure that risks do not move from one company to another and therefore preserving the overall industry sustainability as supported by Nyagah 
INTERNATIONAL JOURNAL OF ACADEMIC RESEARCH IN BUSINESS AND SOCIAL SCIENCES Vol. 10, No. 5, May, 2020, E-ISSN: 2222-6990 @ 2020 HRMARS

(2014). The regression and correlation results revealed that sensitivity to risk had a positive and significant relationship with sustainability of insurance companies as supported by Mushtaq and Hanif (2015).

The null hypothesis, $\mathrm{H}_{0} 1$ : Sensitivity to risk does not statistically significantly influence sustainability of insurance companies in Kenya; was rejected indicated that there was a significant relationship between sensitivity to risk and sustainability of insurance companies in Kenya. Therefore, given the importance of risk management to an insurance company's sustainability, such an important and significant factor should be embedded into the business across all departments, business processes, products and services of all the insurance companies. In conclusion, the insurance company's management and board members must have risk management agenda and reports in all their meetings and performance targets that ensures the right tone on risk management is emphasized at all levels of the company.

The Sensitivity to Risk was found to have a positive and significant effect on sustainability of insurance companies in Kenya. The operations of the board risk committees in an insurance company in addition to the appointment of risk champions to identify and track risks enhance its sustainability. In conclusion, the company's reinsurance programs were key to the companies continued operations in offering service to their customers and hence their sustainability.

The study concluded that insurance companies should ensure they have operational Board risk committees who have skills in risk management, accountancy and actuarial so as to be able to help the company in risk management oversight. The embedment of risk culture through appointment and training of risk champions across the business helps in ensuring that risks are identified and mitigated on time and the culture and attitude is right for insurance business and risk rating. Finally, the right reinsurance programs and counterparties will ensure that the insurance company's capital is secured and the capacity to underwrite business is enhanced.

The insurance companies have heavily invested in systems and technology to enhance recovery and business continuity in case of disaster. However, despite the heavy investments by companies in establishment of disaster recovery sites and business continuity plans they have insignificant influence on sensitivity to risk of sustainability of insurance companies. In the country, risk based supervision was adopted in the country in 2015 but the level of compliance has been quite low as the minimum solvency level has been set at $100 \%$ with the dates of full compliance of $200 \%$ being extended to 2020 . The local insurance industry has greatly advanced. The risk based supervision is a step in the right direction but the model does not capture some factors that enhance an insurance company's performance, sustainability and agility like technological adoption and advancement.

In the country, risk based supervision was adopted in the country in 2015 but the level of compliance has been quite low as the minimum solvency level has been set at $100 \%$ with the dates of full compliance of $200 \%$ being extended to 2020 . The local insurance industry has greatly advanced. The risk based supervision is a step in the right direction but the model does not capture some factors that enhance an insurance company's performance, sustainability and agility like technological adoption and advancement. 
INTERNATIONAL JOURNAL OF ACADEMIC RESEARCH IN BUSINESS AND SOCIAL SCIENCES Vol. 10, No. 5, May, 2020, E-ISSN: 2222-6990 @ 2020 HRMARS

\section{Recommendations}

The Sensitivity to Risk was found to have a positive and significant effect on sustainability of insurance companies in Kenya. The operations of the board risk committees in an insurance firm in addition to appointment of risk champions to identify and track risks enhance its sustainability. In conclusion, the company's reinsurance programs and the establishment of disaster recovery sites and business continuity plans were key to the companies continued operations in offering service to their customers and hence their sustainability. The study concluded that insurance companies should ensure they have operational Board risk committees who have skills in risk management, accountancy and actuarial so as to be able to help the company in risk management oversight. The embedment of risk culture through appointment and training of risk champions across the business helps in ensuring that risks are identified and mitigated on time and the culture and attitude is right for insurance business and risk rating. Finally, the right reinsurance programs and counterparties will ensure that the insurance company's capital is secured and the capacity to underwrite business is enhanced. The insurance companies have heavily invested in systems and technology to enhance recovery and business continuity in case of disaster. However, despite the heavy investments by companies in establishment of disaster recovery sites and business continuity plans they have insignificant influence on sensitivity to risk of sustainability of insurance companies.

\section{References}

AM Best. (2009): Special report on causes of Failure of Insurance Companies?

Amaya, P. A., \& Memba, F. (2015). Influence of Risk Management Practices on Financial Performance of Life Assurance Firms in Kenya: A Survey Study of Kisii County. International journal of Economics, Commerce and Management, pp.978-998

Baxter, N. (2007). Leverage, Risk of Ruin and the Cost of Capital. The Journal of Finance, pp.395-403.

Bhoola, K., Madzhadzhi, T., Narayan, J., Strydom, S., \& Heerden, H. H. (2014). Insurance Regulation in Africa: Impact on Insurance and Growth Strategies. A Paper presented at the Actuarial Society of South Africa's 2014 Convention.

Debra, D., Donaldson, L., \& Davis, J. H. (2015). Stewardship Theory or Agency Theory: CEO Governance and Stakeholder Returns. Australian Journal of Management, pp. 49-65

Field, R. (2006). Performance Management in Insurance Corporations. Journal of Business Administration Online, pp. 135-144.

Haniff, R. H., Pratsch, L. W., Executive, P., Welch, R. A., Denett, P. A., Litman, D. J., \& Tychan, T. J. (2001). Guide to a Balanced Scorecard Performance Management Methodology. Procurement Executives' Association, Available URL: www. oamweb. osec. doc. gov/bsc/guide. htm, accessed, 1.

IRA. (2015) An Assessment of Operational Strategies Influencing the Growth of Insurance Industry in Uasin Gishu County, Kenya. International Journal of Managerial Studies and Research .Volume 2, Issue 10.

Jones, J. (2011). Sustainability and Risk Management. The Insurance Industry and Sustainability.

Mueller, J. W. (2014). The Determinants of Financial Performance in General Insurance Companies in Kenya (Doctoral dissertation, University of Nairobi).

Mwangi, Y. K. (2014). The Effect of Risk Management on Financial Performance of Commercial Banks in Kenya (Doctoral dissertation, University of Nairobi). 
INTERNATIONAL JOURNAL OF ACADEMIC RESEARCH IN BUSINESS AND SOCIAL SCIENCES

Vol. 10, No. 5, May, 2020, E-ISSN: 2222-6990 @ 2020 HRMARS

Nyagah, B. K. (2014). The Effect of Enterprise Risk Management on Financial Performance of Pension Fund Management Firms in Kenya (Doctoral dissertation, University of Nairobi).

Omasete, C. A. (2014). The Effect of Risk Management on Financial Performance of Insurance Companies in Kenya (Doctoral dissertation, University of Nairobi).

Opler, N. W. (1994). The Impact of Business Environmental Factors on Marketing of General Insurance Products in Kenya. Nairobi:

Osiemo, J. M. I. (2015). Effects of Risk Management Practices on Financial Performance of Non-Life Insurance Firms Operating in Kisii County, Kenya (Doctoral dissertation, JKUAT).

Saleem, H., \& Abideen, D. G. (2014). Global talent management. Journal of World Business. 45 (2010) 105-108

Sean, R. (2015). In What Ways Does Government Regulation Influence the Insurance Sector?

Waweru, C., \& Ngugi, K. (2014). Influence of Financial Management Practices on the Performance of Micro and Small Enterprises in Kenya. European Journal of Business Management, pp. 141161. 